\title{
STRATEGIES OF COMBATING CORRUPTION IN NIGERIA: THE ISLAMIC PERSPECTIVE
}

\author{
Usman Sambo ${ }^{*}$, Babayo Sule ${ }^{2}$ \\ ${ }^{1}$ Department of Public Administration, Yobe State University Damaturu, Nigeria \\ 2Department of Political Science, Federal University of Kashere, Gombe, Gombe State Nigeria \\ Corresponding author E-mail : ussambo2@gmail.com
}

\begin{abstract}
Corruption has become a pandemic and a moral burden that bedeviled the world. Corruption is a practice that permeates all societal segments, sectors, activities and it takes various shapes, forms, dimensions, classifications and manifestations. Nearly all countries of the world are affected by the endemic of corruption albeit, in different magnitude with some having lower incidence while others a high rate of occurrence. Corruption has constituted itself as a political and socioeconomic problem worldwide because it leads to misgovernance, deprivation, inequality and squander of scarce public resources which have the concomitant repercussions of poverty, insecurity, joblessness, hunger and malnutrition, poor healthcare services delivery and low quality education. The problem of corruption took a new dimension when it continuously defies various strategies and alternatives proffered by nation-states, international organisations and agencies. One of the outstanding measures that permanently proves workable is the Islamic model which forbids the practice of corruption and ties it with moral burden and spiritual integrity. Hence, this study presented an alternative model with reference to Nigeria as the area of study. The study utilised a conceptual descriptive approach where documented sources were consulted and analysed. The study discovered that despite the existence of various anti-graft agencies, corruption continues in Nigeria unabated which portrays the need for adopting a different approach and that has been provided as the Islamic perspective. The study recommends among several others that the Islamic ethics and morals of detesting corrupt practices and the accompanied sanctions should be integrated in the crusade against corruption.
\end{abstract}

Keywords: Combating, Corruption, Islamic, Nigeria, Perspective, Strategies

\section{INTRODUCTION}

Corruption is a cancer that besieged world countries because it impedes progress and development (Rose-Ackerman \& Palifka, 2016). Corruption disconnects the societal scarce resources from the provision of essential public services and goods, obfuscate the motivation of the people towards engaging in productive ventures, erodes public confidence and support on government and institutions and instigate civil upheavals (Rose \& Peiffer, 2018), Poor governance, weak institutions and stringent public control by the government coalesce into corrupt practices (Maddow, 2019). Corruption is prevalent around the world particularly developing countries. There are different forms of corruption, each with exceptionally different drivers and implications (Holmes, 2015). Corruption has undesired consequences for a society such as dwarfing economic growth, escalating poverty and inequality, and it prevents the provision of public goods and services (Rose-Ackerman, 2013). Thus, understanding what motivates corruption, how it permeates public institutions and individuals' life, and how its repercussions affect progress and development in the society are necessary to guide policies towards combating the menace (Miller, 2016; Sule \& Sambo, 2020).

* Copyright (c) 2021 Usman Sambo and Babayo Sule

This work is licensed under a Creative Commons Attribution-ShareAlike 4.0 International License.

Received: January 10, 2021 ; In Revised: January 19, 2021 ; Accepted: January 25, 2021 
Nigeria is one of the countries that records dismal performance in corruption surveys of various forms (Smith, 1961). The country has developed a notorious reputation in corruption scandals both endogenously and exogenously by both its rulers and citizens (Oluyitan, 2016). Several reports (National Bureau of Statistics/United Nations Office on Drugs and Crimes, 2019; Transparency International, 2020a) portray an alarming rate at which corruption is deeply eaten into the fabric and garments of the Nigerian society. The reports indicate that public institutions are enmeshed in corruption scandals based on perception of Nigerians to the level of higher percentage in a scale of score. The security operatives, judiciary, political office holders, bureaucrats, civil servants, public are all found to have been engaged in giving bribe or collecting according to NBS and UNODC Report 2020. The African Union reported in 2018 that over $\$ 600$ billion was stolen from the Nigerian treasury by its ruling class since political independence in 1960.

Several factors were attributed to the existence of corruption in Nigeria. The elite conspiracy of a vicious circle of collaboration for power control towards personal aggrandisement is one of them (Page, 2018). The social chasm in Nigeria in terms of ethnic cleavages, religious affiliations and regional belongings help escalate corrupt practices because the elite could easily manipulate these elements against the law using the sentiments and psychology of their cohorts (Campbell, 2020). Weak institutions and a fragile legal system coupled with constitutional loopholes enable for the corrupt ones to perpetrate their evil act with impunity since they could muster the effrontery to engage the services of the best paid lawyers to protect them against the jaws of the law (Osoba, 1996). The teeming ignorant and politically dissocialised population is another reason why the citizens could not scrutinise and monitor corruption allegations against their elected leaders. According to other views, the prolonged and exercabated military rule in the country aided the spread of corruption (Igiebor, 2019).

Corruption manifested in Nigeria in different ramifications. Political corruption is the biggest of them. Political office holders are chastised of stealing public resources to the tune of billions of Naira and dollars since 1960 to 2020 (Transparency International, 2020c). Contracts are awarded and inflated for kickbacks, extortion, bribery, nepotism, abuse of public office and abuse of due process, manipulation of electoral process, violation of electoral regulations, spending beyond limit, vote buying, money laundering, public servants engage in contracts as against the rules of engagement, favouritism, godfatherism and forging of certificates are all manifestations of corruption in Nigeria (Sule, Azizuddin, etal., 2017; Sule, Sani, et al., 2018b, 2018a; Sule \& Tal, 2018). Corruption has several impacts on the Nigerian state. The few ruling elites amass wealth beyond their utilisation at the expenses of the majority impoverished poor (Hope $\mathrm{Sr}$, 2017). Nigeria is naturally rich being the $10^{\text {th }}$ top oil producing country in the world, $7^{\text {th }}$ most populous in the world, the highest Growth Domestic Product (GDP) in Africa and one of the 25 highest GDP in the world according to International Monetary Fund (IMF) in 2020 (International Monetary Fund, 2020). With a population of over 200 million as at 2020, a geographical area of land in square kilometres of 983, 213 $\mathrm{km}^{2}$, it is the $35^{\text {th }}$ largest country in terms of landmass in the world. The country is a federal political arrangement with a Federal Capital Territory Abuja (FCTA), 36 states, 774 local governments, six geopolitical zones, rich in oil, fertile agricultural land and other diverse mineral resources including cocoa, rubber, timber, iron, gold, uranium, limestone, coal, and a suitable environment for livestock production, poultry and fish farming (National Bureau of Statistics, 2019). The country has received over $\$ 600$ billion in oil revenue since 1960 but all these aforementioned leverages could not translate into meaningful growth and development owing to corruption. The country is the headquarters of world poverty in 2019 according to World Poverty Clock with over 90 million of the population as poor, one of the low performing 
in terms of Corruption Performance Index (CPI) based on the 2020 Report by Transparency International. Corruption has caused a poor socioeconomic and political backwardness in the country.

There are several measures put in place by the Nigerian Government to combat corruption. The civil servants and public office holders are made compulsorily to declare their assets on assumption of office and after their departure by the provision of Code of Conduct Bureau (CCB). The Public Complain Commission (PCC) was also established in 1980 to address complains related to misconduct of public servants in office (Sule, Azizuddin, et al., 2018). Additionally, the Independent Corrupt Practices and other Related Offences (ICPC) was introduced in 2001 to cater for all complains related to corrupt practices by civil servants and public. Not fully satisfied, the Government in 2002 introduced the Economic and Financial Crimes Commission (EFCC) to handle issues that border on betrayal of public trust, financial crimes, stealing of public resources and other offences (Sule, Azizuddin, et al., 2018). Also, the Money Laundering Act was enacted in 2011 to prevent corrupt officials from sending their loot abroad all in an effort to curb corrupt practices. Unfortunately, all the measures taken could not yield the desired result of minimising corruption because of weak legal enforcement regime (Sule, Azizuddin, et al., 2018). Thus, it is glaring that the measures adopted in Nigeria to fight corruption have failed and there is a need for a more plausible alternative. This is the reason why this study is carried out which emphasised on integrating the Islamic perspective or strategy of combating corruption.

Islam has a fashion for detesting all forms of corruption spectacularly from the perspective of preventive measures. Islamic assault on corruption is palpable in its spiritual, moral and political quest for equality, justice and meritocracy (Iqbal, 2002). Islam discourages corruption through an ambitious penchant for equalising all members of the society including the rulers with the governed to avoid the feeling of superiority or moral corruption that will transform into political one (Mevliyar, 2008). Islam has provided several strategies of combating corruption using some frightening morals and promises of reward. The aim from the Islamic perspective is to prevent the practice from taking place unlike the Western or secular approach which is flexible in believing that corruption can be tackled using sanctions after it occurs. Islam prefers that it did not occur in the first place (Alazzabi et al., 2020). This study established that strategies of fighting corruption in Nigeria have failed and that Islamic approach is the best alternative. While, both studies exist of corruption in Nigeria and Islamic stance on corruption in general, the attempt in applying the strategies of Islamic solutions in Nigerian environment was not made prior to this study in a research of this nature. This is the contribution to the body of knowledge that this work aspires to actualise.

\section{METHODOLOGY}

This study uses a conceptual descriptive approach in which documented sources are consulted and analyzed (Creswell \& Creswell, 2017). Besides this research also uses thematic and Hadith research methods (Darmalaksana, 2020), namely by looking for some related literature to be analyzed so as to form a conclusion - a statement. This research focuses on corrupt behavior in Nigeria which is increasing from time to time, the Nigerian government has done various ways to reduce and even prevent the occurrence of corrupt behavior, unfortunately until now it has not shown good progress. 


\section{RESULT AND DISCUSSION}

\section{Perspectives on Corruption}

Corruption is as old as the existence of mankind himself ranging from spiritual, moral, financial and office corruption (Uslaner, 2017). Corruption has been given various meanings, interpretations and classifications by academics, international organisations and agencies, policymakers and public analysts. The English word corruption is derived from the Latin corrumpere, something that fails to meet a particular standard (Rose et al. 2019). Transparency International defines corruption as "the abuse of entrusted power for private gain." (The World Bank, 2020). The TI went ahead to classify corruption into grand and petty corruption. Grant corruption is the worst because it is the one that is perpetrated in public office by politicians and bureaucrats by abuse of office and awarding reward and kickbacks for political loyalists using public resources. Petty corruption is demand for a bribe by public officials or offer of bribe by individuals to the public officials for a service offered (The World Bank, 2020). Rose-Ackerman (1999) identifies corruption as a cultural problem associated with giving of bribes, gifts, prizes, tips, patronage, kleptocracy by politicians through bi-lateral monopolies and dominated states, electoral processes in democracies that are accompanied with electoral systems that envisage buying political influence and vote buying, all of which require domestic reform and international collaboration to be addressed. RoseAckerman (2013) and Standing (2016) identified the study of corruption as the function of political economy in the society where democratic political system makes certain pattern of wealth distribution which does not commensurate with equality of voting leading to some section of the society purposely favoured against the other in the process. Girling (1997) could notagree less with the above views by RoseAckerman (2013) in terms of explaining the linkage between democracy and corruption through buyoff and kickbacks. Related to the above but in a different approach, the Broken Window Theory postulated in 1982 by George Kenneth and James K. Wilson saw corruption as a broken social order just like a broken window in a house. Broken windows are unrepaired community controls breakdown allowing for serious crimes with the tendency to flourish which makes some societies tolerant of corrupt practices. The Theory linked its assumption with some set of social progress such as the country's performance in CPI indicating level of corruption, how corruption directly affects human development in terms of service delivery, the level of perceived corruption and civil liberties and establishing a linear relationship between corruption and democracy relating to good governance (Alford, 2012).

Corruption takes different categories including varieties of crimes, bribery, extortion, graft, embezzlement, various forms of fraud, patronage, influence, favouritism and abuse of offices by public office holders. Another form of corruption is the 'White Collar Corruption' which is the corruption by the corporate world in the process of contracts procurement and execution. State corporate crime and corruption is responsible for globalisation of corruption (Kratcoski, 2018). There are several factors that are associated with the drivers of corruption in any society. Absence of good governance, accountability, transparency and a responsive civil citizenry are perceived as the drivers that germinate corruption in any society (Bakar \& Ghosh, 2014). Poverty and embezzlement of resources by public officials will lead to corruption because there will be no enough money to provide essential services after squander and that will create shortage of infrastructure such as roads, education, health, electricity which impoverished the subjects (Fisman \& Golden, 2017). Muir \& Gupta (Muir \& Gupta, 2018), analysed the cause of corruption from the Anthropological point of view where they emphasise that it is cause by the violation of rules of engagement, how people in that society react to the transgression and the strategies used by actors to negotiate their safety. In such societies, the practice will continue. Hough (2013) suggests that the politics 
of anti-corruption crusades which made the agencies heavily relying on politicians made the entire anticorruption process "a dog that could barely raise a whimper". Jordan (1999) and Katzarova (2019) post it that elites hide under the auspice of democracy to penetrate societal resources with their conspiracy of wealth accumulation through organised crimes and international finance, criminalisation of the international finance system and corrupting democratic transitions and consolidations. In some developing countries like Nigeria, Ghana and Kenya, failure of institutions, weak legal enforcement and a largely ignorant crowd enable for the ruling class to escape corruption scandals freely and that has been related with the nature in which the incidences are increasing in these areas (Hope $\mathrm{Sr}, 2017$; Oluyitan, 2016; Smith, 2008).

Corruption manifested globally based on the reports of official theft across countries, cybercrimes, money laundering and the performance of countries in CPI which is release annually by Transparency International. The Transparency International Corruption Perception Index (CPI) is the most popular and reliable manifestation and measurement of global corruption level. The CPI ranked 180 countries and territories in 2019 by their perceived level of public corruption, according to data collected in the territories by stakeholders. The Index uses a scale of zero to 100, where zero is highly corrupt while 100 very clean. From the 2019 results, more than two-thirds of the 180 countries scored below 50 with an average score of just 43 . The data shows that many countries are performing below their previous records. The top five (5) performers are Denmark 87, New Zealand 87, Finland 86, Singapore, 85, Sweden 85 and Switzerland 85 while the bottom five (5) are Venezuela 15, Yemen, 15, Syria 13, South Sudan 12 and Somalia 9. In overall, no country has earned a perfect score. The regional scores indicate that Western Europe and European Union scores the highest of 66 while Sub-Saharan Africa is the low performer with just an average score of 32 . Nigeria, which is the area of study ranked 146 out of 180 studied countries with a score of 26/100. The Report identified political corruption as the biggest cause and threat to combating corruption globally as observed by the Chair of Transparency International in the following words: "Governments must urgently address the corrupting role of big money in political party financing and the undue influence it exerts on our political systems" as a panacea towards minimising global corruption (Transparency International, 2020b). Philp (2015) earlier saw this warning sign when he emphasised that political corruption is the problem and it has no answers to it in the near future. Building on the above Report, the Global Financial Integrity (2020) opines that corruption is becoming worse after 20 years of assessment from 1998 to 2018. Of the countries studied, the Report shows that in the CPI, ten percent worsened their scores; 59 percent remained relatively unchanged; and only about one third (32 percent) improved their scores over the period. This suggests that, according to the CPI, corruption levels were perceived to have either gotten worse, or stayed the same in nearly two-thirds of the countries examined over the last two decades (Rowden \& Wang, 2020).

In another report, the Transparency International observed that corruption is being exported and it has become severe during the COVID 19 pandemic lockdown across the globe. The summary of the Report read: "Bribery of foreign public officials has huge costs and consequences for countries across the globe and those costs have become more severe during the COVID-19 pandemic. With so many cases of foreign bribery occurring in health care, we cannot afford for corruption to cost any additional lives" (Transparency International, 2020). The Report above rates the performance of 47 leading global exporters, including 43 countries that are signatories to the Organisation for Economic Cooperation and Development (OECD) Anti-Bribery Convention, in cracking down on bribery of foreign public officials by companies operating abroad. The Report further observed that the economies of the world countries are sharply affected by the effects of COVID 19 and this has led to desperation and intense competition for 
securing contracts by leading companies across the globe. In the process, bribery and corruption of large magnitude was exported (Transparency International, 2020). Furthermore, corruption manifested globally in the level of money laundering which is estimated at around $\$ 800$ billion to $\$ 2$ trillion equivalent of 2-5\% of global GDP (Cheek, 2020). Africa has the highest record of money laundering of $\$ 88.6$ billion annually and Nigeria has the top value of $47 \%$ of the total world money laundering crime (Kuhlmann, 2020). Another sector in which corruption of both public officials and private individuals is affecting the global economy because of the corrupt nature of the action is cybercrime which reached the toll of $\$ 600$ billion each year since 2014 which tantamount to $1 \%$ of global GDP. The crime is expected to reach $\$ 10.5$ trillion annually by 2025 if adequate measures are not taken. Corrupt nature of national elites denied many states from designing a secure cyberspace which is an associated factor that leads to the crime (Lewis, 2020).

Corruption has several impacts on the growth and development of any society. The money meant for the provision of essential services are diverted by the illegal act of public office holders leading to slow economic growth, low level of development, poor and weak political institutions and myriads of socioeconomic problems including poverty, unemployment, disease, hunger, malnutrition, insecurity and a huge infrastructure gap (Rose-Ackerman \& Palifka, 2016). It slows macroeconomic performance in the society (Ivanyna et al., 2018). Africa particularly south of the Sahara is the most affected in this regard (Blundo et al., 2013). However, the developed countries are not spared in corrupt practices. Schweizer (2018) and Schweizer (2020) established various high level corruption scandals of the US leaders to the extent that he mentioned that "Anyone who does not see the connection between the Clintons' official government power and their ability to raise money overseas is clearly not paying attention" when making reference to one of the US leaders in present time. Corruption compromises global peace and security because it leads to illicit transaction in weapons and other harmful goods that are not meant for a category of individuals (Rotberg, 2009b), because most of the domestic national conflicts are fueled by proliferation of illicit Small Arms and Light Weapons (SALW) and their possession by illegal armed groups which perpetrate violence on states (Chayes, 2015; Rose-Ackerman \& Palifka, 2016) resulting from corruption that is associated with trafficking and the marriage of politics with illicit profits. Even the course of nuclear proliferation is accompanied with corrupt practices where a considerable money meant for social redistribution to achieve equality are channeled towards the manufacture of unused weapons (Rotberg, 2009a) as well as global terrorism which would not have flourish but for the corrupt nature of global key players (Teets \& Chenoweth, 2009).

There are several efforts in combating corruption worldwide. Individual countries such as America, Britain, France, Germany, Canada, Italy, Hong Kong, Singapore and several other world countries are making efforts in reform towards countering corruption and corrupt practices (Dixit, 2018). Many countries also established anti-corruption agencies in Africa, Asia, Europe and America (Édes, 2016). The OECD countries made an agreement on assault against corruption in which the member countries all signed the agreement instantly (Rothstein, 2011). Other regional bodies such as the European Union (EU), African Union (EU), Association of South East Asian Nations (ASEAN) and other regional bodies made an embodiment of the fight against corruption that encompasses prevention of illicit financial flows, money laundering, cybercrimes, repatriation of the proceeds of corruption scandals and other measures of combating corruption (Lambsdorff, 2007). The United Nations is recently expending a huge resource in undertaking studies and suggestions towards curbing corruption globally. These efforts are followed by World Bank and other financial institutions. The most visible body is the Transparency International which formed an Index and is carrying out studies on corruption level of world countries with suggestions 
for policy implications annually (Yadav \& Mukherjee, 2016). However, it should be understood that domestic measures towards curbing corrupt practices which requires an unflinching commitment of political will is the most fundamental in terms of addressing corruption problem than global institutions which in most cases lack the legal enforcement to sanction defaulters (Rotberg, 2019).

\section{Understanding Corruption from Islamic Viewpoint}

Islam as a religion emboldens spiritual, political, economic and sociocultural aspects of man's life and the main aspiration of the religion is to foster unity, peace, justice, equality, prosperity, freedom and wellbeing of mankind. Islam unequivocally forbids all forms of waste and corruption because it leads to socioeconomic problems. Corruption is differently perceived in Islam from the conventional Western perspectives even though, most of the meanings and forms are similar. Islam prohibits economic, managerial, financial, political, environmental, social and ethical corruption which is explicitly prohibited because of their consequences on societies. Islam establishes proactive, preventive, detecting and reactive procedures to control corruption and prescribes how to avoid its harmful consequences (Alazzabi et al., 2020). Iqbal (2002) argue that "there is zero tolerance for bribery in Islam, and Islam rejects any idea that bribery serves as 'the grease that oils the economic wheels'." (Kamal, 2019). The term corruption has been mentioned severally in the Quran. For instance, in one of the Chapters:

"Do not eat up one another's property unjustly nor bribe with it the judges in order that you may knowingly and wrongfully deprive others of their possessions." (Quran Chapter 2 Verse 188).

In another verse, Allah warns as a deterrence to mankind from corrupt practices as follows:

“Corruption has appeared on land and in the sea for what men's hands have earned, that He may make them taste a part of that which they have done, that they may return." (Quran Chapter 30 Verse 41).

From the above verses, the logic of the Islamic perception of corruption is any form of bribery, illegal seizure of others properties, acquiring of wealth through illicit means, corrupt behaviour and other forms of evil and the target is to prevent the offences from occurring not to punish the offenders. Additionally, the Glorious Quran mentioned many evil acts as corruption such as murder (Quran 5:33 \& 34 and Quran 2:178), prohibition of stealing (Quran 5:38 \& 39), prohibition of usury (Quran 2:275, Quran 2:276, Quran 3:130, Quran 4:161 and Quran 30:39), ending injustice and ensuring a just society (Quran 57:25), enhancing equality and forbidden of racism (Quran 49:13), on ensuring a just and quality leadership free of selfishness with mutual consultation (Quran 3:159 \&160), on prohibition of cheating and deception (Quran 9:119), on the illegality of lying (Quran 63:1 and Quran 40:28), on prohibition of transgression (Quran 2:85, Quran 2:193, Quran 2:217, Quran 5:2), on prohibition of intoxication and harmful commodities (Quran 2:219, Quran 4:43 and Quran 5:90-91), prohibition of violence (Quran 2:229-237, Quran 4:19, 4:25 and 4:34), prohibition of illegal business transactions and treachery (Quran 2:275, Quran 4:3, Quran 4:29, Quran 4:180, Quran 4:90, Quran 12:60 and Quran 17:35) and prohibition of mutual suspicion and backbiting all as forms of corruption (Quran 17:36 and Quran 49:12). All the above mentioned practices are considered as forms and manifestations of corruption from the perspective of Islamic viewpoint especially the Quran.

There are also numerous Prophetic Hadiths on the nature and meaning of corruption. These Hadiths could not be narrated here all of them because of specio temporal variable factor. Few of them are however, observed here. The Prophet (PBUH) curse he who gives bribe or collect (Al Tirmidhi, 1336) 
which means bribery is corruption in Islam. Also, the Prophet (PBUH) says that whosoever intercedes for his brother and accepts a gift from it has open a door of usury, reported by Abu Dawud: 3541. In another Hadith, the Prophet (PBUH) narrated that all are shepherds and all would be asked of their responsibilities (Bukhari 6719 and Muslim 1829). The Prophet was narrated to have said in an authentic Hadith reported by Bukhari on prohibition of transaction on all forms of harmful consumables including liquor, dead animals, pork, idols and all forms of intoxicants (Bukhari, 2010). The Prophet also declares that whatever Allah Has made unlawful is corruption and all its proceeds are also unlawful (Ahmad, 2013). The Prophet (PBUH) identifies all forms of uncertainties as corruption in a Hadith reported by Abu Dawud (2015), Tirmidhi (2011), Al Nasa'I, (2014), Al Darami, (1990) and Ibn Majah (2016). The Prophet (PBUH) also identifies hoarding of foodstuffs and other materials as corruption as reported by Abu Dawud 2990. All the Hadiths which are few among the retinue of Prophetic Hadiths on the nature of corruption in Islam point towards practices that are illegal, perceived as 'Fasad' (literal meaning of corruption in Islam). The major aim from the Islamic viewpoint is adopting preventive measures. Since a Muslim believed in the Day of Judgement, the warnings from the Quran and Hadiths on the consequences of wrongdoing and breaking of norms suffice to deter a firm and true believer from corrupt practices. For instance, Ibn Qayyim Al Jawzi argues that there is a long essay where scholars debated on love and fear of Allah. He summarised that there is still an open vacuum for arguments on whether it is the love of Allah that is preventing a believer from sins and corrupt practices or the fear of his punishment and which of the two is the best? (Ibn Qayyim, 2018). Either of them is positive if it will prevent corruption.

\section{Corruption in Nigeria: Indices, Measurements, Causes, Manifestations, Impacts and Combating Strategies}

Corruption is one of the biggest challenges of development in Nigeria. The phenomenon is a cankerworm that is eaten deep into the fabric and garments of the Nigerian society for many decades. The existence of various policies and anti-graft agencies can attest to the highest level in which corruption manifest in Nigeria today. Many scholars like Jain (2001), Hope (1999), Ogundiya (2010) and Mohammed (2013) are of the view that, official corruption is the major obstacle against good governance and national development in Nigeria. Corruption in Nigeria is complex, multifaceted and polyvalent (Pierce, 2016). Corruption is so pervasive in Nigeria that it has turned public service for many decades into a kind of criminal enterprise. Graft has fueled political violence, denied millions of Nigerians access to even the most basic health and education services, and reinforced police abuses and other widespread patterns of human right violations (Human Rights Watch, 2019). It is seen by some scholars (Bailey, 2006; Balboa \& Medalla, 2006) as the bane of transparency, good governance, accountability, political stability, socioeconomic development and overall national development. The corruption within the broader political system includes the demand of electoral politics, the extensive use of patronage in political appointments, and the use of dubious transactions. It extends towards corruption within the public sector which is mainly considered on payment for employment and public procurement and the grand corruption within specific governmental agencies (Smith, 2014). The systemic corruption in the Nigerian political system leads to a particularistic political culture. This, in essence, is a system in which the government's treatment of citizens depends on their status or position in the society (Asobie, 2012). There is a direct correlation between political leadership and corruption in Nigeria. A careful analysis of the various regimes in Nigeria reveals that leadership and corruption in Nigeria are positively correlated (Ogbeidi, 2012). Ogundiya (2009) describes Nigerian political corruption and corrupt practices in Nigeria as;" Clientelism, Prebendalism and Patrimonialism". 
There are various explanations advanced by scholars on the major causes of corruption in Nigeria including; poverty and poor condition of work (Asobie, 2012), economic bargains and activities of multinational corporations (Knuckles, 2006; Rose-Ackerman \& Palifka, 2016), rent and rent seeking (Mauro, 1998), weak political institutions and low human development indicators (Eguae-Obazee, 2014; Mbaku, 2010), social and political factors (Dike, 2001), and prolong military rule (Shehu, 2004). Godfatherism is another major political factor associated with corrupt practices in Nigeria (Olarinmoye, 2008; Sule et al., 2018b). The process of party financing provides a loophole for the kleptocratic Nigerian elite to siphon money from public treasury, spend above limit, violate rules through vote buying and bribery of electoral officials (Sule et al., 2017).

Corruption manifested in Nigeria from various perspectives. For instance, Achebe (2012) estimated the amount of money stolen by Nigerian leaders since independence at $\$ 400$ billion, a figure, which is also reported by the former Chairman of the Economic and Financial Crimes Commission (EFCC), Malam Nuhu Ribadu (2013), an anti-graft agency that is saddled with the task of combating corruption and other related crimes. The African Union (2018) Report an estimated $\$ 600$ billion as stolen funds from the Nigerian State since 1960. In the post-2015 General Election, revelation of corruption scandals uncovered a shocking thievery of the highest magnitude, the Dasuki Scandal where $\$ 2.1$ billion (N1,100,000,000,000 one trillion and one hundred billion Naira) earmarked for procurement of weapons to fight Boko Haram was diverted by the former ruling PDP for campaign. A panel was set up under the leadership of the National Commissioner Baba Shettima to investigate the allegations. Again, about N23.29 billion ( $\$ 46,580,000$ million) was allegedly disbursed to INEC officials by the then administration of Goodluck Jonathan. The money was according to investigators released by the former Minister of Petroleum Mrs. Diezani Allison Maduekwe to influence the outcome of the Election in favour of the ruling party (Sule et al., 2018a). Another report is that by the Civil Society Legislative Advocacy Centre (CISLAC) and Transparency International UK in 2017 which revealed that the former Nigerian army chiefs stole as much as $\$ 15$ billion (N7,500,000,000, 000 seven trillion and five hundred billion) through fraudulent arms procurement deals. In a Conference in State House Abuja, the Chairman of the Presidential Advisory Committee Against Corruption Itse Sagay disclosed that, fifty top government officials and private businessmen allegedly diverted about $\$ 7.5$ billion (N6.7 trillion at that time) to themselves between 2006 and 2013 at the expense of ordinary Nigerians (Sagay, 2017).

The above are indices that are showing the nature and pattern of corruption in Nigeria. However, measurement of corruption is the most difficult aspect in the study of the subject matter. This is because it is a political economic and social issue that involves human actors and variant actions that occur simultaneously and not possibly in a linear way. One of the most reliable indicators that are used to measure corruption in Nigeria is the Corruption Perception Index by Transparency International. The country is constantly and continuously among the low performers since the commencement of the survey in 1996. The alarming issue is the way in which the country is performing far lower than in 1990s and 2000s. The CPI uses a scale of $0-100$ by conducting a survey of some selected section of the society annually. The 2019 Report shows that Nigeria scores a disappointing 26/100. In Nigeria, the survey since 1990s indicates that Nigeria is one of the worst performers up to 2020 as shown in table 1.

Another measurement of corruption indices in Nigeria is the one carried out by the National Bureau of Statistics (NBS) in collaboration with United Nations Office on Drugs and Crimes (UNODC) in 2019 which is a local study of corruption in Nigeria undertaken indigenously (National Bureau of Statistics, 2019). The study used the methodology of survey where 33,000 Nigerians were interviewed from across the 36 states and the FCT. The indices designed for the questionnaire is to identify how corruption is 
perceived and related among Nigerians especially in their dealings with public officials. The study revealed a shocker that nearly $30.2 \%$ of Nigerians are involved in the proceeds of corruption either by giving bribe or collecting and around N400 billion was paid as bribe in just 2019 alone. About $9 \%$ of Nigerians based on the survey saw corruption as the most challenging problem that is slowing Nigeria's development. direct bribery requests by public officials accounted for 60 per cent of all bribery transactions in Nigeria in 2019. Around two thirds of bribes (67 per cent) are paid before a service is provided by a public official, according to the 2019 survey. More than 93 per cent of all bribes paid in 2019 were paid in cash and the prevalence of institutions involved in collecting bribery is Police with 44\%, prosecutors $33 \%$, judiciary $31 \%$ and Customs and Immigration 31\%. Men likely pay more bribe than women and the citizens' response is that bribes are paid not necessarily but to speedy up or facilitate a process of services. Vote buying in the electoral process and nepotism in the recruitment process and promotion in the public sector took a large share of bribery according to the survey. In a related report released earlier in 2018 by Page (2018), he observes that "electoral corruption and kleptocratic capture of political party structures unlock corruption opportunities across a range of other sectors and that corruption is ripe across the country's economic sector". Corruption by sector according to Page (2018) taxonomy shows that political corruption and political parties is a big key player in polluting the Nigerian environment with bribery. This is followed by media corruption, electoral corruption, legislative corruption, bureaucratic corruption, petro corruption, trade related corruption, industrial corruption, agricultural corruption, infrastructure corruption, power sector corruption, financial sector corruption, environmental corruption, security sector corruption, judicial corruption, anticorruption corruption, education sector corruption, health sector corruption and humanitarian sector corruption. This indicates that virtually there is no sector in Nigeria that has not been penetrated by corruption.

Table 1. Corruption Perception Index of Nigeria 1996-2020

\begin{tabular}{cccc}
\hline Year & Perception Index & No. of Countries Selected & Rating \\
\hline 1996 & 1.2 & 54 & 54 \\
1997 & 1.3 & 52 & 52 \\
1998 & 1.9 & 85 & 81 \\
1999 & 1.9 & 99 & 98 \\
2000 & 1.9 & 90 & 90 \\
2001 & 1.6 & 102 & 100 \\
2002 & 1.7 & 91 & 90 \\
2003 & 1.4 & 133 & 132 \\
2004 & 1.6 & 145 & 144 \\
2005 & 1.9 & 158 & 154 \\
2006 & 2.2 & 160 & 142 \\
2007 & 2.2 & 183 & 127 \\
2008 & 2.2 & 183 & 127 \\
2009 & 2.7 & 180 & 130 \\
2010 & 2.7 & 174 & 134 \\
2011 & 2.4 & 183 & 143 \\
2012 & 2.7 & 174 & 139 \\
2013 & 2.5 & 175 & 144 \\
2014 & 2.7 & 176 & 136 \\
\hline & & & \\
\hline
\end{tabular}


IJIK, Vol.11 No. 1: 12-28

Strategies of Combating Corruption in Nigeria: The Islamic Perspective

Usman Sambo and Babayo Sule

\begin{tabular}{llll}
2015 & 2.6 & 167 & 136 \\
2016 & 2.1 & 176 & 136 \\
2017 & 2.7 & 180 & 148 \\
2018 & 2.6 & 180 & 144 \\
2019 & 2.6 & 180 & 146 \\
\hline
\end{tabular}

Source: Transparency International (2020a).

In Nigeria's security sector, defense sector and police corruption are destabilising and compounding security challenges in conflict hotspots like the Lake Chad Basin, the Middle Belt, and the Niger Delta. Educational, health, and humanitarian sector corruption, meanwhile, saps the country's social capital and has an outsized impact on its most vulnerable citizens (Page, 2018). Political corruption in Nigeria has several implications. Corruption leads to leadership crisis and this has undermined democratic values of trust, credibility of government, and good governance by flouting or subverting formal process. Leadership crisis and corruption in electioneering processes, and the executive and legislative bodies reduced accountability, transparency, integrity and distorts quality representation in policy making (Sule et al., 2018b). Socially, Nigeria suffers from epileptic power supply, industrial decay and poor road networks. The state of insecurity to lives and properties in the country is cataclysmic. Health infrastructures have collapsed as average Nigerian becomes victim of preventable and curable diseases resulting from political and bureaucratic corruption (Page, 2018). Economically, corruption has crippled the Nigerian micro and macroeconomics extending its real consequences on the life of Nigerians. The Nigerian economy has been in comatose despite its enormous resources and potential for growth and development. For example, the Human Development Report in 2011 shows that about $70 \%$ of Nigerians lives in poverty spending less than $\$ 1.9$ per day. Nigeria emerged as headquarters of world poverty in 2019 based on the World Poverty Clock Report. Corruption has many negative impacts on the culture of Nigeria. For instance, Nigerian political culture has been that of money politics, vote buying, godfatherism, violence, rigging, manipulation of election results and other electoral irregularities which made Nigerian democratic culture an apathetic one and backward (Aiyede, 2008).

There are many responses and measures taken by the Nigerian Government to combat corruption. One of the approaches toward curbing the menace of corruption is institutional strategy. The Code of Conduct Bureau was established since 1970s to ensure compliance, accountability and transparency of the public office holders. They are to declare their assets on assumption of office and when leaving. Another institution is the Public Complain Commission which is responsible for handling complains and petitions from the public on misconduct of public office holders. The PCC was established in 1980. The Independent Corrupt Practices and Related Offences Commission (ICPC) was established on 29th September 2000 as the agency for fighting corruption. The Commission is to receive complaints, investigate and prosecute offenders. It is also to educate and enlighten the public about the practices that are considered as bribery and corruption. It failed to make serious prosecutions and curb corrupt practices as expected. With the failure of the ICPC, the Nigerian government did not relent in its efforts to remedy the evil of corruption in Nigeria. Another anti-corruption agency was established called the Economic and Financial Crimes Commission (EFCC) in April 2003. The Commission is empowered to prevent, investigate, prosecute and penalise economic and financial crimes and is charged with responsibility of enforcing the provisions of other laws and regulations relating to economic and financial crimes including Economic and Financial Crimes Commission Establishment Act 2004, the Money Laundering Act 1995, the Money Laundering Prohibition Act 2004, the Advance Fee Fraud and Other Fraud Related Act 1995, the Failed Banks and Financial Malpractices in Banks Act 1994, the Banks and Other Financial Institutions Act 
1991 and Miscellaneous Act 1998 (Aiyede, 2008). EFCC has recorded significant achievement in the fight against corruption and financial crimes in Nigeria especially in its early inception from 2001 to 2007. However, it faced many challenges including the perception of the public towards the Commission as a tool used by the incumbent government to hunt and intimidate opposition and perceived threats. As such, it has failed to be effective due to lack of political will. Thus, this study concludes that all the strategies introduced by the Nigerian Government failed to address the problem of corruption because even the CCB which monitors assets of public office holders is not functioning since most of them are not declaring. Hence, this study provides an alternative; the Islamic model or perspective.

\section{The Islamic Alternative to Combating Corruption in Nigeria}

It is believed by this study that the Islamic model of combating corruption will work in Nigeria. It should be note that many parts of Nigeria operate Islamic law especially in Northern Nigeria and the Nigerian 1999 Constitution provides for the legal position of Shariah Courts. Section 275 of the Constitution provides for the creation of states Shari'ah Courts. Corruption cases can be handled through Shari'ah Courts. It may also be integrated in the mainstream competent courts of jurisdiction for nationwide application to those who are interested. It will not be easy in a religiously volatile environment like Nigeria where every policy and action are interpreted using political and religious manipulation. The experience of Nigeria during the re-introduction of Shari'ah law in 1999 was still unpalatable. Christians in the country christened the term islamisation and other synonymous nomenclatures. A stiff resistance, misrepresentation, deliberate manipulation, counter efforts and other recalcitrant resistance were staged. The same can be said of the introduction of Islamic Banking (Non-Interest Banking) in 2011. Despite the fact that world leading secular countries like United States, United Kingdom, Japan, Canada, and others are operating the system, several unnecessary outcries and negative condemnation accompanied with campaign of calumny to thwart the establishment of the Bank followed. Since the negative comments and censure could not prevent the re-introduction of Shari'ah law and Islamic Banking against all odds, the same can happen with the introduction of strategies of combating corruption using Islamic alternative.

Islam has three basic strategies for addressing the issue of corruption. The first is the moral and spiritual deterrence taking the approach of prevention. The second is the punishment, some mild, others capital, depending on corrupt practice or activity sanctioned in this world with the good hope that it is forgiven against the Hereafter. The last strategy is the anticipation that the corrupt will not go free as they will face the wrath of their Creator in the Day of Judgement. In the first strategy, the Glorious Quran mentions in several verses too numerous to mention on the abstention from sins, corrupt behaviours, evil practices and moral degradation. In most cases, such admonition for abstention are accompanied with the pledge of a beautiful reward in this world and the Hereafter. The Glorious Quran mentions that mankind is clearly guided on good and evil (Quran 90:8-10). There are several Prophetic Hadiths too numerous to mention on prevention of corruption in the society for both the leaders and followers. For instance, the Prophet (PBUH) said whosoever deceives us is not among us as reported by Bukhari and in another Hadith, he said that every traitor will have a banner on the Day of Judgement it will be said this is the betrayer of so and so. In other Hadiths, the Prophet (PBUH) said that anybody that shows keen interest on leadership do not appoint him. He also said that anyone that we appoint in a leadership responsibility and uses the opportunity to enrich himself will not enter paradise responding on the Zakat collector who returned with a separate personal wealth. He also emphasises that people are obsessed with leadership and wealth and they are all source of regret on the Day of Judgement (All reported by Bukhari). 
In the second instance, several Quranic verses as mentioned in the section on Islamic view of corruption revealed what a sinner or a perpetrator of a corrupt behaviour should expect as a punishment for his corruption because government and leadership in Islam is a trust that must be faithfully observed (Quran 4:58), and betrayal of trust is strictly forbidden (Quran, 8:72). The Quran also speaks in condemnation of corruption and its perpetrators $(2: 205 ; 26: 151 ; 30: 41)$. For instance, a fornicator who is unmarried will be flog 100 times while a certified married fellow will be stone to death once a factual evidence beyond doubt is established. A thief is destined for amputation if his stealing reaches a certain quantity and it is confirmed. A transgression is bound to be retaliated by law such as murder, injury and robbery. In the last category, some corrupt practices such as usury, betrayal, treachery, violation of moral and spiritual regulations are all punishable in the Hereafter. Hence, leaders who emerge either by election or appointment in Nigeria for political offices or public offices should be made to undergo compulsory workshop on training towards understanding how to prevent corruption upon themselves and in the society and the expected punishment accruable to certain corrupt practices in this world with specification on those that are punishable on the Day of Judgement. This will awaken and frighten many to abstain from such practices. Without any serious expenditure, corruption can be tackled.

Anti-corruption measures are alsotaken in the history of Islam by various Caliphs. Umar Al-Khattab, the second Caliph, introduced measures of fighting bribery and corruption of officials through confiscation of personal wealth accumulated during the tenure of office. This was done to prominent figures among the Prophet's companions, Abu Hurairah, Amri Al-Aas, Nafi Amri, Saad bin Abi Waqas, and Khalid Al-Walid, the governors respectively of Bahrain, Egypt, Mecca, Kufa and Sham, among others, who were found to have accumulated wealth which they did not have prior to employment. Some of them indulged in trading activities. Umar (RTA) did not blame or accused them of corruption but rather felt that it was not necessary for a leader who is involved in handling of public affairs to engage in business transaction for wealth accumulation which will possibly divert his attention from discharging his responsibility as expected. Such expropriation was not confined to government officials but also extended to merchants, contractors and dignitaries who conducted business with the government and accumulated disproportionate amounts of wealth (Kamal, 2019). Kamal (2019) added that expropriation of assets of corrupt officials was eventually institutionalised under the Abbasid Caliph, Ja'afar al-Mansur, when a department was established for handling expropriation matters in cases of unwarranted enrichment. The same approach can be applied in Nigerian context under the provision of Islamic law or Shari'ah on combating corruption. It will help in discouraging many public office holders from corrupt practices since they are quite aware that what they accumulate may not end up in their personal account. They may lose it.

\section{CONCLUSION}

Corruption is a global problem and countering it is continuously evading the international community because the strategies introduced are not effective. Nigeria is one of the countries that has the highest prevalence of corruption in all its characteristic ramifications from bribery to extortion, vote buying, nepotism, favouritism, stealing of public resources and other forms. Corruption in Nigeria is caused by several factors as observed above most importantly weak institutions and failure of legal enforcement regime to sanction the offenders appropriately. Corruption manifested in Nigeria where it was reported that over $\$ 600$ billion was stolen from 1960 to date and the Nigeria's CPI revealed a low score of just 26/100. Corruption has affected the political, economic, social and cultural development of Nigeria being a rich and populous country raped by its ruling elites for many decades of its resources. Several institutional strategies such as CCB, PCC, ICPC and EFCC that were introduced failed to address corruption 
phenomenon in Nigeria. The above development prompted this study to conclude that the strategies adopted by the Nigerian State towards combating corruption are not working and may not likely work. Hence, the search for an alternative model. The Islamic approach or strategies were found to be plausible, comprehensive and effective in curbing societal corruption and are therefore recommended for adoption and integration with the existing strategies particularly by the states that are operating Shari'ah as a litmus test for future full implementation.

\section{REFERENCES}

Achebe, C. (2012). There was a country: A memoir. Penguin.

AFRICAN UNION. (2018). Fighting Against Corruption in Africa.

Ahmad, bin H. (2013). Sunan Ahmad: Hadith Collection. Darul Fajr.

Aiyede, E. R. (2008). The role of INEC, ICPC and EFCC in combating political corruption. International foundation for electoral system.

Al Nasa'i. (2014). Sunan Nasa'i: Hadith Collection. Darul Fajr.

Al Tirmidhi. (2011). Sunan Tirmidhi: Hadith Collection. Darul Fajr.

Alazzabi, W. Y. E., Mustafa, H., \& Latiff, A. R. A. (2020). Corruption and control from the perspective of Islam. Journal of Financial Crime.

Alford, R. P. (2012). A broken windows theory of international corruption. Ohio St. LJ, 73, 1253.

Asobie, H. A. (2012). Conceptual, Theoretical and Empirical Issues on the Interface between Corruption, Governance And Development. Mohammed, Aluaigba and Kabir Eds. Cited Above.

Bailey, J. (2006). Corruption and democratic governability in Latin America: Issues of types, arenas, perceptions, and linkages. Unpublished Paper Delivered at the 2006 Meeting of the Latin American Studies Association, San Juan, Puerto Rico, 15-18.

Bakar, S. M. A., \& Ghosh, R. N. (2014). Corruption, Good Governance and Economic Development: Contemporary Analysis and Case Studies (Vol. 28). World Scientific.

Balboa, J., \& Medalla, E. M. (2006). Anti-corruption and governance: The Philippine experience. APEC Study Center Consortium Conference, 1-28.

Blundo, G., de-Sardan, J.-P. O., Arifari, N. B., \& Alou, M. T. (2013). Everyday corruption and the state: Citizens and public officials in Africa. Zed Books Ltd.

Bukhari, A. (2010). Authentic Collection of Prophetic Tradition. Darul Fajri Lil Turath.

Campbell, J. (2020). Perceptions of Corruption in Nigeria Remains High, According to NGO. US: Council on Foreign Relations. NGO. https://www.cfr.org/blog/perceptions-corruption-nigeria-remain-highaccording-ngo on 5th

Chayes, S. (2015). Thieves of state: Why corruption threatens global security. WW Norton \& Company.

Cheek, M. (2020). "Money Laundering Around the World". Smart Search. Smartsearch. https://www.smartsearch.com/resources/blog/money-laundering-around-the-world

Creswell, J. W., \& Creswell, J. D. (2017). Research design: Qualitative, quantitative, and mixed methods approaches. Sage publications.

Darami, A. (1990). Collected Hadith of Al Darami. Al Maktub Al Islami.

Darmalaksana, W. (2020). Studi Penggunaan Analisis Pendekatan Ilmu-ilmu Sosial dalam Penelitian Hadis Metode Syarah. Khazanah Sosial, 2(3), 155-166.

Dawud, A. (2015). Sunan Abu Dawud: Hadith Collection. Darul Fajr.

Dike, V. E. (2001). Democracy and political life in Nigeria. Ahmadu Bello University Press.

Dixit, A. (2018). Anti-corruption institutions: Some history and theory. In Institutions, governance and the control of corruption (pp. 15-49). Springer.

Édes, B. W. (2016). REGIONAL ANTI-CORRUPTION INITIATIVES IN ASIA. Routledge Handbook of Corruption in Asia.

Eguae-Obazee, G. A. (2014). The Effects of Corruption on the Inflow of Foreign Direct Investment into Ten Sub-Saharan African Countries: Using Ghana and Nigeria as Discussion Points. Wilmington University (Delaware).

Fisman, R., \& Golden, M. A. (2017). Corruption: What everyone needs to know. Oxford University Press. 
Girling, J. (1997). Corruption, capitalism and democracy (Vol. 4). Psychology Press.

Holmes, L. (2015). Corruption: a very short introduction (Vol. 426). Oxford University Press, USA.

Hope, K., \& Chikulo, B. (1999). Corruption and development in Africa: Lessons from country case studies. Springer.

Hope Sr, K. R. (2017). Corruption and Governance in Africa: Swaziland, Kenya, Nigeria. Springer.

Hough, D. (2013). Corruption, anti-corruption and governance. Springer.

Human Rights Watch. (2019). Nigeria: Public Sector Corruption. Hrw. https://www.hrw.org/worldreport/2019/country-chapters/nigeria

Ibn Majah. (2016). Sunan Ibn Majah: Hadith Collection. Darul Fajr.

Ibn Qayyim, A. (2018). Patience and Gratitude. Ta Ha Publishers.

Igiebor, G. O. (2019). Political Corruption in Nigeria: Implications for Economic Development in the Fourth Republic. Journal of Developing Societies, 35(4), 493-513.

International Monetary Fund. (2020). Real GDP Growth: Annual Percent Change. IMF. https://www.imf.org/external/datamapper/NGDP_RPCH@WEO/OEMDC/ADVEC/WEOWORLD

Iqbal, Z. (2002). Governance and Corruption: Can Islamic Societies and the West Learn from Each Other? by Zafar Iqbal and Mervyn K. Lewis. American Journal of Islam and Society, 19(2), 1-33.

Ivanyna, M., Mourmouras, A., \& Rangazas, P. (2018). The Macroeconomics of Corruption. Springer Texts in Business and Economics.

Jain, A. K. (2001). Corruption: A review. Journal of Economic Surveys, 15(1), 71-121.

Jordan, D. C. (1999). Drug Politics: dirty money and democracies (Vol. 1). University of Oklahoma Press.

Kamal, M. H. (2019). "Fighting Corruption: An Islamic Perspective". New Straits Times. NST. https://www.nst.com.my/opinion/columnists/2019/07/507029/fighting-corruption-islamicperspective

Katzarova, E. (2019). Global Anti-Corruption Talks in the 1970s and 1990s: The Story of Two Utopias. In The Social Construction of Global Corruption (pp. 213-234). Springer.

Knuckles, J. . (2006). A Study of Corruption's Causes in Botswana and Nigeria. Unpublishedworks. https://unpublishedworks.files.wordpress.com/2013/03/a-study-of-corruptions-causes-inbotswana-and-nigeria.pdf

Kratcoski, P. C. (2018). Introduction: Overview of Major Types of Fraud and Corruption. Fraud and Corruption, 3-19.

Kuhlmann, M. (2020). Africa Could Gain \$89 Billion Annually by Curbing Illicit Financial Flows.

Lambsdorff, J. G. (2007). The institutional economics of corruption and reform: Theory, evidence and policy. Cambridge university press.

Lewis, J. . (2020). Economic Impact of Cybercrime: At $\$ 600$ Billion and Counting No Slowing Down.

Maddow, R. (2019). Blowout: Corrupted democracy, rogue state Russia, and the richest, most destructive industry on earth. Crown.

Mauro, P. (1998). Corruption: Causes, Consequences, and Agenda for Research. Journal of Finance And.

Mbaku, J. M. (2010). Corruption in Africa: Causes, consequences, and cleanups. Lexington Books.

Mevliyar, E. (2008). Corruption from the Islamic perspective. International Journal of Islamic and Middle Eastern Finance and Management, 1(1).

Miller, S. (2016). Corruption and Anti-corruption in Policing--Philosophical and Ethical Issues. Springer.

Mohammed, U. (2013). Corruption in Nigeria: A challenge to sustainable development in the fourth republic. European Scientific Journal, 9(4), 118-137.

Muir, S., \& Gupta, A. (2018). Rethinking the anthropology of corruption: An introduction to supplement 18. Current Anthropology, 59(S18), S4-S15.

National Bureau of Statistics/United Nations Office on Drugs and Crimes. (2019). Corruption in Nigeria: Patterns and Trends. Second Survey on Corruption as Experienced by the Population.

National Bureau of Statistics. (2019). Human Poverty Index in Nigeria.

Ogbeidi, M. M. (2012). Political leadership and corruption in Nigeria since 1960: A socio-economic analysis. Journal of Nigeria Studies, 1(2).

Ogundiya, I. S. (2009). Political corruption in Nigeria: Theoretical perspectives and some explanations. The Anthropologist, 11(4), 281-292.

Ogundiya, I. S. (2010). Corruption: The bane of democratic stability in Nigeria. Current Research Journal 
of Social Sciences, 2(4), 233-241.

Olarinmoye, O. O. (2008). Godfathers, political parties and electoral corruption in Nigeria. African Journal of Political Science and International Relations, 2(4), 66-73.

Oluyitan, F. E. (2016). Combatting Corruption at the Grassroots Level in Nigeria. Springer.

Osoba, S. O. (1996). Corruption in Nigeria: historical perspectives. Review of African Political Economy, 23(69), 371-386.

Page, M. T. (2018). New taxonomy for corruption in Nigeria. Carnegie Endowment for International Peace. Philp, M. (2015). The definition of political corruption. Routledge Handbook on Political Corruption, 1729.

Pierce, S. (2016). Moral Economies of Corruption. Duke University Press.

Ribadu, M. . (2013). Corruption and National Development in Nigeria. National Conference.

Rose-Ackerman, S. (1999). Political corruption and democracy. Conn. J. Int'l L., 14, 363.

Rose-Ackerman, S. (2013). Corruption: A study in political economy. Academic Press.

Rose-Ackerman, S., \& Palifka, B. J. (2016). Corruption and government: Causes, consequences, and reform. Cambridge university press.

Rose, R., \& Peiffer, C. (2018). Bad governance and corruption. Springer.

Rotberg, R. I. (2009a). Corruption, global security, and world order. Brookings Institution Press.

Rotberg, R. I. (2009b). How corruption compromises world peace and stability. Corruption, Global Security, and World Order, 1-26.

Rotberg, R. I. (2019). The corruption cure: How citizens and leaders can combat graft. Princeton University Press.

Rothstein, B. (2011). The quality of government: Corruption, social trust, and inequality in international perspective. University of Chicago Press.

Rowden, R., \& Wang, J. (2020). The Global Crisis of Corruption. Global Financial Integrity. Gfintegrity.

Schweizer, P. (2018). Secret Empires: How the American Political Class Hides Corruption and Enriches Family and Friends. almohreraladbi.

Schweizer, P. (2020). Profiles in Corruption: Abuse of Power by America's Progressive Elite. almohreraladbi.

Shehu, A. Y. (2004). Combating corruption in Nigeria-bliss or bluster? Journal of Financial Crime.

Smith, D. J. (2008). A culture of corruption: Everyday deception and popular discontent in Nigeria. Princeton University Press.

Smith, D. J. (2014). Corruption complaints, inequality and ethnic grievances in post-Biafra Nigeria. Third World Quarterly, 35(5), 787-802.

Standing, G. (2016). The corruption of capitalism: Why rentiers thrive and work does not pay. Biteback Publishing.

Sule, B., Azizuddin, M., Sani, M., \& Mat, B. (2017). Political party financing and corruption in Nigeria's Fourth Republic: The case of 2015 General Elections. Arts Social Sciences Journal, 8(1), 276-298.

Sule, B., Azizuddin, M., Sani, M., \& Mat, B. (2018). Impact of political party financing on integrity of 2015 General Election in Nigeria. Tamkang Journal of International Affairs, 22(2), 165-218.

Sule, B., \& Sambo, U. (2020). THE 2019 GENERAL ELECTION AND THE POLITICS OF INCONCLUSIVE ELECTION IN NIGERIA: A REVIEW OF THE AFFECTED STATES. Khazanah Sosial, 2(3), 105-124.

Sule, B., Sani, M. A. M., \& Mat, B. (2017). Independent National Electoral Commission and campaign financing monitoring in Nigeria: The 2015 general elections. Journal of International Studies, 13, 15-31.

Sule, B., Sani, M. A. M., \& Mat, B. (2018a). Corruption and electoral process in Nigeria: examining the 2015 general election. Journal of Techno Social, 10(1).

Sule, B., Sani, M. A. M., \& Mat, B. (2018b). Godfatherism and political party financing in Nigeria: Analysing the 2015 general election. Geografia-Malaysian Journal of Society and Space, 14(1).

Sule, B., \& Tal, M. K. (2018). Impact of Money on Nigerian Politics: Exploring the General Elections in the Fourth Republic. Asia Pacific Journal of Education, Arts and Sciences, 5(2), 89-98.

Teets, J. C., \& Chenoweth, E. (2009). To Bribe or to Bomb: Do Corruption and Terrorism Go Together? Corruption, Global Security, and World Order, 167-193.

The World Bank. (2020). The Fight Against Corruption: Taming Tigers and Swatting Flies. 


\section{IJIK, Vol.11 No. 1: 12-28}

Strategies of Combating Corruption in Nigeria: The Islamic Perspective Usman Sambo and Babayo Sule

Transparency International. (2020a). Corruption Perception Index. Transparency. https://www.transparency.org/en/cpi/2019

Transparency International. (2020b). CPI 2019 Global Highlights. Retrieved. Transparency. https://www.transparency.org/en/news/cpi-2019-global-highlights

Transparency International. (2020c). Exporting Corruption Progress Report 2020: Assessing Enforcement of the OECD Anti-Bribery Convention. In Transparency International.

Uslaner, E. M. (2017). The historical roots of corruption: Mass education, economic inequality, and state capacity. Cambridge University Press.

Yadav, V., \& Mukherjee, B. (2016). The politics of corruption in dictatorships. Cambridge University Press. 